NBER WORKING PAPER SERIES

\title{
OPENNESS AND GROWTH: \\ WHAT'S THE EMPIRICAL RELATIONSHIP?
}

Robert E. Baldwin

Working Paper 9578

http://www.nber.org/papers/w9578

\author{
NATIONAL BUREAU OF ECONOMIC RESEARCH \\ 1050 Massachusetts Avenue \\ Cambridge, MA 02138 \\ March 2003
}

This paper is part of an NBER conference volume (University of Chicago Press, forthcoming) edited by Robert E. Baldwin and L. Alan Winters resulting from a joint NBER-CEPR International Seminar on International Trade (ISIT) on Challenges to Globalization in Stockholm, Sweden, May 24-25, 2002. The views expressed herein are those of the authors and not necessarily those of the National Bureau of Economic Research.

(C2003 by Robert E. Baldwin. All rights reserved. Short sections of text not to exceed two paragraphs, may be quoted without explicit permission provided that full credit including Cnotice, is given to the source. 
Openness and Growth: What's the Empirical Relationship?

Robert E. Baldwin

NBER Working Paper No. 9578

March 2003

JEL No. F13, F14, F32

\begin{abstract}
$\underline{\text { ABSTRACT }}$
There is still disagreement among economists concerning how a country's international economic policies and its rate of economic growth interact, despite a number of multi-country case studies utilizing comparable analytical frameworks, numerous econometric studies using large cross-country data sets, and important theoretical advances in growth theory. This paper briefly surveys this literature and points out the main reasons for the disagreements. Particular attention is given to an important study by Francisco Rodriguez and Dani Rodrik (2001) criticizing the conclusion of a number of recent multicountry statistical studies that openness is associated with higher growth rates. Rodriguez and Rodrik show that openness simply in the sense of liberal trade policies seems to be no guarantee of faster growth. However, the conclusion of most researchers involved in either country studies or multi-country statistical tests that lower trade barriers in combination with a stable and non-discriminatory exchangerate system, prudent monetary and fiscal policies and corruption-free administration of economic policies promote economic growth still seems to remain valid.
\end{abstract}

Robert E. Baldwin

Department of Economics

University of Wisconsin-Madison

Madison, WI 53706

and NBER

rebaldwi@facstaff.wisc.edu 


\title{
Openness and Growth: What's the Empirical Relationship?
}

\author{
Robert E. Baldwin, University of Wisconsin-Madison and NBER
}

\section{Introduction}

The manner in which the international economic policies of governments affect the rates of growth of their economies has long been a subject of controversy. This situation continues today. Despite a number of multi-country case studies utilizing comparable analytical frameworks, numerous econometric studies using large cross-country data sets, and important theoretical advances concerning how a country's international economic policies and its rate of economic growth interact, there is still disagreement among economists concerning the nature of the relationship.

There are several reasons for this. A key one is the difference among investigators in the manner they define the issue being studied. Some authors focus on whether there is a causal relationship between such variables as increases in trade or foreign direct investment and increases in growth rates (or between increases in growth and increases in trade or investment), no matter what the reasons for the changes in these economic variables. However, most authors are interested in the effects of differences in government policies on economic growth. The impact of policies affecting the "openness" of a country to trade and investment or its "inwardorientation" or "outward-orientation" is the subject of many studies. But, of course, just how broadly one defines such terms greatly affects one's conclusions about a particular country or set of countries. One can interpret openness in narrow terms to include only import and export taxes or subsidies as well as explicit nontariff distortions of trade or in varying degrees of broadness to cover such matters as exchange-rate policies, domestic taxes and subsidies, competition and 
other regulatory policies, education policies, the nature of the legal system, the form of government, and the general nature of institutions and culture.

Differences in the quality and detail of the data being analyzed are another source of disagreement among economists on the subject. Those who study trade and growth relationships among developing countries are greatly hampered by the lack of good data even on such matters as levels of import protection, and they often are forced to undertake case studies. While many insights have been revealed from such studies about the nature of the development process and its relationship with trade, some are reluctant to draw broad generalizations from them because of their specificity and the bias that the personal viewpoints of the authors may introduce into the analyses. In contrast, while econometric analyses based on quantitative data concerning trade and growth for a cross section of countries do permit broad generalizations, these studies are limited by the scope and comparability of available quantitative data. Differences in what investigators regard as appropriate econometric models and tests for sensitivity of the results to alternative specifications that may be based in part on the personal policy predilections of the authors can also result in significant differences in the conclusions reached under such quantitative approaches.

The purpose of this paper is to survey briefly the views of economists and policymakers since around the end World War II concerning the relationships between economic openness and growth, indicating how and why these views have significantly changed over the last fifty years and pointing out the main reasons for the disagreements. Section II examines the 1950s and 1960s when import substitution was the dominant growth policy in the developing countries and there was also extensive government intervention in many industrial countries aimed at influencing growth rates. Section III considers the period from the 1970 s into the 1990 s, in 
which the findings from an increasing number of studies of the growth experiences of individual countries caused more and more economists and policymakers to become skeptical about the growth merits of import substitution policies and to begin to advocate more export-oriented, outward-looking trade policies. Section IV briefly outlines some of the new relationships between trade and growth brought out by the so-called "new growth" literature of the late 1980s and early 1990s which, together with the development of new econometric techniques for dealing with time series data, has stimulated new efforts to unravel the relationships between trade and growth through cross-countries statistical analyses. Section V briefly reviews the major studies of this period, all of which reach the general conclusion that openness is associated with higher growth rates. This conclusion has, however, been recently challenged in a detailed, carefully reasoned critique of these papers by Francisco Rodriguez and Dani Rodrik (2001). These authors contend that, in fact, because of various methodological shortcomings in these studies, one should conclude that there is very little evidence that trade openness is significantly associated with economic growth. Section V summarizes the criticisms of the paper by Rodriguez and Rodrik. Section VI concludes with an evaluation of the new studies and the critique by Rodriguez and Rodrik.

\section{The Widespread Acceptance of Import Substitution Policies as the Means to}

\section{Stimulate Economic Growth}

As more and more countries obtained their independence from the colonial powers in the period shortly after the end of World War II, a widespread view developed among economists and policymakers that the best way for these countries to develop more rapidly was to stimulate industrialization by adopting import-substitution policies. There seemed to be a number of good reasons for such an approach at the time. The political leaders of the newly independent nations 
were keenly aware not only that most of the countries from whom they obtained independence had much higher per capita income levels and were much more industrialized but that their former rulers had imposed economic policies in the past which discouraged industrialization within the new nations. To these new leaders, industrialization seemed to offer the possibility of achieving faster growth, higher per capita income levels and the attainment of the economic and military power needed for national security.

An economically sensible way of achieving industrialization seemed to be to restrict imports of manufactured goods for which there already was a domestic demand in order both to shift this demand toward domestic producers and permit the use of the country's primary-product export earnings to import the capital goods needed for industrialization. There also appeared to be a number of examples where high levels of import protection in the nineteenth and twentieth century had contributed positively to industrialization. Although Great Britain had adopted a policy of free trade during its period of rapid growth in the nineteenth century, the United States seemed to industrialize and prosper by imposing high import duties on manufactures for much of the later part of the nineteenth century. Germany and France also adopted protectionist policies during this period, as did Japan after 1900. ${ }^{1}$ The impressive degree of industrialization achieved by the Soviet Union in the 1920s and 1930s and by China after 1949 by pursuing inward-looking policies were additional historical examples that impressed the leaders of the newly independent nations.

The so-called infant industry argument first set forth in 1791 by Alexander Hamilton, further elaborated by Friedrich List (1856), and accepted by many classical and neoclassical economists as the major theoretically valid exception to the case for worldwide free

\footnotetext{
${ }^{1}$ See O'Rourke (2000) and Clemens and Williamson (2001) for evidence supporting the positive effects of tariffs on growth. Also see Irwin (2002) for some contrary evidence.
} 
trade provided economic support for import substitution policies. John Stuart Mill, who first formalized the argument in economic terms, argued that it takes time for new producers in a country to become "educated to the level of those with whom the processes are traditional" and thus for their unit costs to decline. The infant industry argument maintains that during the temporary period when domestic costs in an industry are above the product's import price, a tariff is a socially desirable method of financing the investment in human resources needed to compete successfully with foreign producers.

Soon after World War II, Raul Prebisch (1950), the Secretary General of the United Nations Economic Commission for Latin America and later the founder and Secretary General of the United Nations Conference on Trade and Development (UNCTAD), among others argued that the infant industry argument was applicable to the entire manufacturing sector and not just to a single industry. He also claimed that an ongoing secular decline in the prices of primary products (the exports of the less developed countries) relative to the prices of manufactured goods (the exports of the developed countries) and the low elasticity of demand for primary products made expansion in the production of primary products unattractive. Focussing on producing labor-intensive manufactured goods, e.g., clothing, for export purposes also did not appeal to most less developed countries at this time because of the belief that a balanced industrial structure, such as existed in most developed countries, was necessary to achieve their goal of high per capita income levels and, moreover, because high levels of import duties and other import barriers still existed in the developed countries on most of these goods.

Although most economic leaders of less developed countries looked favorably on the strategy of import substitution, they also often found themselves backed into such a policy somewhat inadvertently. Because of the shortage of goods these countries suffered during World 
War II and the economic expansion plans of their new leaders, there was a tremendous demand on their part for both capital goods and consumer goods. This meant that their existing foreign exchange reserves were quickly used up, with current export earnings being unable to fill the gap between demand and supply at existing exchange rates. Consequently, most of these countries felt forced to impose foreign exchange and import controls to conserve their available export earnings and to establish a rationing system for the available foreign exchange to ensure that consumer necessities such as food and medicine, key intermediate inputs such as fuel, and essential capital goods could be imported in sufficient quantities to prevent serious political unrest and still permit the pursuit of their development goals. One consequence was that very high levels of implicit protection were put in place on so-called "nonessential" manufactured goods.

Import substitution policies actually worked quite well initially. The high prices of imported nonessentials shifted domestic demand for these goods from foreign to local producers with the result that there were significant increases in the output of simple manufactured goods as governments provided domestic producers with the foreign exchange needed to import key intermediate inputs and capital goods. Many manufacturing activities consisted largely of simply assembling the components of goods produced abroad, e.g., cars. Since the production of most of these products intensively utilized the type of labor that was relatively abundant in the newly industrializing nations, namely, unskilled labor, the adverse effects on economic efficiency of these early import substitution efforts were not sufficient to offset the growth effects of the import substitution policies. Moreover, in this early period, the overvalued domestic currencies resulting from the tight exchange controls and expansionary production 
policies not only did not seem to reduce earnings from primary-product exports significantly but kept import prices of needed capital goods and intermediate inputs relatively low.

As import substitution policies continued and a number of developing countries extended these policies to cover more and more intermediate inputs and capital goods, the drawbacks of such a policy approach became increasingly apparent. In particular, the hardships imposed on the export sector began to have adverse growth effects. An overvalued currency meant that the number of units of foreign exchange received by exporters remained low while, at the same time, these producers were forced to purchase more and more intermediate inputs and capital goods domestically at high prices. The resulting squeeze on profit margins forced them to curtail export production. The higher skill and technology requirements for the more complex intermediates and capital goods and lack of large domestic markets needed to achieve efficient levels of production of these goods also worsened the profit outlook for domestic producers. At the same time, aggressive expansionary activities by governments and private businesses fueled greater inflationary pressures with the result that large government budget deficits and balanceof-payments deficits became commonplace. The ensuing budget and balance-of-payments crises were often met by still tighter controls over exchange rates and imports and more extensive government intervention in the economy. The net outcome was generally a slowing in the growth rate compared to the early period of import substitution.

Given the widespread agreement among economists today that that the import substitution strategy for did not work out well for most developing countries, an important question to ask is why so many economists were wrong in their predictions that such an approach would be successful in raising long-run growth rates for these countries. What went wrong with our analytical thinking? In my view, two mistakes we made were an uncritical acceptance of the 
infant industry argument and a failure to take account of the macroeconomic consequences of such a policy when applied to all manufacturing. ${ }^{2}$

Consider the argument set forth earlier that new producers need to be protected for a temporary period so they can acquire the experience and production skills that will make them as efficient as their long-time foreign competitors. As James Meade (1955) pointed out many years ago, the existence during the early period of production of higher costs than foreign competitors is, by itself, an insufficient reason to justify tariff protection on economic efficiency grounds. If unit costs in an industry are low enough after the learning period to yield a discounted surplus of revenues over costs (and thus indicate a comparative advantage for the country in producing the product), it should be possible for firms to raise sufficient funds in the capital market to cover their initial excess of expenditures over revenues. These circumstances are no different from those in which firms go to the capital market for funds to cover the excess of expenditures over receipts during the early stages of production because of the need to purchase indivisible units of physical capital. Imperfections in capital markets may prevent access to capital markets but the existence of market imperfections is a quite different case for government intervention than the infant industry argument.

As Meade (1955) also noted, the key argument on which the infant industry case must rest relates to technological externalities associated with the learning process. For example, consider the matter of acquiring the knowledge about local production techniques needed to compete effectively with foreign producers. An entrepreneur who incurs these costs of discovering the best way to produce a particular good faces the problem that this information may become freely available to other potential local producers, who can utilize it at the same time as the initial firm but without incurring the full costs of the knowledge acquisition.

\footnotetext{
${ }^{2}$ Also see, Krueger (1997).
} 
Competition from these other producers could then either drive up factor prices or push down the product's price to levels where the initial firm is unable to recover its costs of gaining this knowledge. Realizing that this outcome is possible, firms will be discouraged from undertaking the initial knowledge-acquisition costs. ${ }^{3}$

The imposition of a temporary protective duty is, however, no guarantee that individual entrepreneurs will undertake additional investment in knowledge acquisition. An import tax raises the domestic price of a product and, from the viewpoint of the industry as a whole, makes some investments in knowledge more profitable. But individual producers still face the same externality problem as before, namely, that other firms will copy, with little cost to themselves, any new technical knowledge discovered by the firm and drive the product's price down to a level where the initial firm will be unable to recoup its costs of acquiring this knowledge. If there were always some technologically fixed time lag between the introduction of a new, cheaper production technique and the change in product or factor prices caused by the entry of the firms who copy the new production method, a duty would operate to make investment in knowledge acquisition more profitable for the individual firm in the industry. But, to make a point too often ignored in such discussions, the speed with which firms respond to market opportunities is itself a function of the level of profit prospects. A duty will make it worthwhile for firms to incur the costs of acquiring the knowledge discovered by other firms faster and also to move into production more rapidly at high output levels. What is needed, of course, is a subsidy to the initial entrants into the industry for the purpose of discovering the better production techniques.

\footnotetext{
${ }^{3}$ See Baldwin (1969) for a more complete discussion of this point and its policy implications. Hausmann and Rodrik (2002) have also recently discussed the development implications of this externality problem.
} 
Up to the post-World War II period when some economists began to extend the infant industry argument to all manufacturing, economists had generally framed this argument for temporary protection in partial equilibrium terms. It focused on a single industry, and it was assumed that the temporary import protection granted had no appreciable effect on such macroeconomic variables as exchange rates, aggregate exports and imports, and monetary or fiscal policies. Early proponents of aggressively protecting large segments of the manufacturing sector did not fully appreciate the implications of their policy suggestions on these macroeconomic variables. They did not, for example, take sufficient account of the adverse effects of import substitution on aggregate exports and, thus, on the foreign exchange earnings so essential for importing the capital goods and essential intermediate inputs needed to permit the expansion of the manufacturing sector. Nor did they realize the extent to which government actions to conserve foreign exchange by limiting imports of luxury consumer goods would make the domestic production of these goods the most attractive for domestic entrepreneurs and thus bias the pattern of production in a direction that the government did not particularly want. They also failed to appreciate the extent of the budget and inflationary pressures that would be generated by the development actions of governments and domestic producers. Indeed, it was the macroeconomic crises associated with unsustainable import deficits for central banks, unmanageable government budget deficits, runaway inflation, etc. that had the greater effect in finally turning most countries away from import substitution policies than a realization of the serious resource misallocation effects of these policies.

\section{The Shift to Outward-Oriented Policies}

The first group of developing countries to shift from an inward-oriented to outwardoriented approach to development were located in the Far East, specifically Taiwan, Singapore 
and South Korea. (Hong Kong had long pursued open trade and investment policies.) South Korea, for example, was characterized by extensive quantitative controls over trade and international payments from the time it separated from North Korea in 1945 through the end of the Korean War in 1953. Inward-looking actions continued to dominate government development policy after 1953, with an increasingly elaborate multiple exchange rate system being established in the attempt to deal with the problems of a large trade deficit and an overvalued exchange rate. ${ }^{4}$ While a large currency devaluation took place in 1961 along with efforts to liberalize the trade and payments system, this liberalization effort ended in 1963 as rapid inflation was fed by excessively expansionary fiscal policies and a poor crop. However, a further liberalization effort begun in 1964 and 1965 was much more successful so that by 1966 the trade and payments regime was fairly liberal compared with earlier years. The country became increasingly outward-oriented as the government adopted other policies that encouraged exports of manufactured goods.

Even though they undertook periodic attempts to liberalize their trade and payments regimes, most other developing countries continued to follow what was basically an import substitution approach to growth until the 1980s. However, the debt crisis of 1982 convinced many developing-country governments that inward-looking policies were no longer sustainable, particularly for smaller countries. They had borrowed heavily in international markets in order to cope with the trade-deficit problem associated with the import substitution approach only to find that the high and sustainable growth rates sought still did not materialize and, instead, that they were left with massive international debts they could no longer service. Such traditional

\footnotetext{
${ }^{4}$ See Frank, Kim and Westphal (1975) for a detailed discussion of Korea's development experience during this period.
} 
adherents to the import substitution approach as Argentina, Chile, Mexico, Turkey, Ghana, and Uganda began to adopt more outward-looking policies.

While the inability to borrow the funds needed to reestablish their import-substitution regimes and the remarkable growth record of more and more East Asian countries under outward-oriented policies were probably the main immediate reasons for the shift in growth policy, the gradual shift in thinking by economists both in academia and in international organizations such as the World Bank, the International Monetary Fund and even the United Nations Commission for Latin America in favor of outward-looking over inward-looking policies also was an important factor.

This change in conventional thinking by economists and policymakers about the best policy approach to promote growth in the developing countries was significantly influenced by a series of detailed country studies together with some cross-country statistical analyses of the import substitution process and by new theoretical modeling of the interactions between trade and growth. Both the studies of commercial policies in developing countries directed by Ian Little, Tibor Scitovsky, and Maurice Scott (1970) and by Bela Balassa (1971) utilized the newly formalized concept of the effective rate of protection to compare import substitution policies across industries and countries. ${ }^{5}$ This concept measures protection on a value-added basis rather than on the basis of the final price of a product and thus takes account of the level of protection on intermediate inputs as well as the final product. It brings out the point that, if a good is exported without any export subsidy but the exporter must purchase protected domesticallyproduced intermediate inputs, the primary factors involved in the value-added process are actually penalized compared to free trade. Similarly, if there are no duties on the intermediate 
inputs or they are lower than those on the final product are, the primary factors producing the value-added are protected to a greater degree than the rate of protection on the final product indicates.

Both the Little, Scitovsky and Scott (1970) and Balassa (1971) studies brought out the fact that the average rate of protection of value-added in manufacturing was extraordinarily high in most developing countries - - much higher than nominal rates of protection and often exceeding 100 percent. Moreover, there was great variability among industries and broad sectors that often seemed to make little economic sense. An extreme example was Chile's effective rate of protection in 1961 of 2,884 percent for processed foods in contrast to 300 percent for nondurable consumer goods (Balassa, 1971, p. 54). Perhaps, most important, however, was the degree to which the studies demonstrated the discrimination against exports, mainly agricultural and mineral products. In some countries, there actually were negative rates of protection in these sectors, e.g., agriculture in Pakistan and mining and energy in Malaysia (see Balassa, 1971, p.54). Both sets of studies recommended reducing the average levels of effective protection and, in particular, reducing the discrimination against exports.

Two other noteworthy studies of developing countries were ones directed by Anne Krueger (1978) and Jagdish Bhagwati (1978) and by Demetris Papageorgiou, Michael Michaely, and Armeane Choksi (1991). These studies investigated particular episodes of inward-looking and outward-looking policy actions by considering not only changes in levels of import protection and export subsidization but the array of macroeconomic policies utilized by governments, e.g., monetary policy, fiscal policy, and, especially, exchange rate policy, to promote import substitution or deal with its consequences. The Bhagwati-Krueger project

\footnotetext{
${ }^{5}$ The countries covered by the studies directed by Little, Scitovsky and Scott were Argentina, Brazil, India, Mexico, Pakistan, the Philippines, and Taiwan, while those investigated by the Balassa and his associates were Brazil, Chile,
} 
focused on the effective exchange rates faced by importers and exporters, i.e., the nominal rates for imports and exports corrected for various export subsidies and for import tariffs and nontariff barriers, respectively. ${ }^{6}$ Following broad guidelines, the individual country-researchers in the Papageorgiou-Michaely-Choksi study were asked to construct an annual index of the degree of trade liberalization. ${ }^{7}$ Both these sets of studies reached the same conclusion as the two earlier ones, namely, that import-substitution policies generally do not produce sustainable increases in long-run growth rates and that outward-looking policies are more appropriate for achieving this goal. They also both go into considerable detail about the process of moving from an inwardlooking to outward-looking policies and, in particular, the sequencing of trade and exchange-rate liberalization and the set of other policies, such as monetary, fiscal and competition policies, that should accompany the liberalization process.

There were also cross-country econometric studies in the 1970s and 1980s that attempted to test the relationship between trade and economic growth. For example, using information from the country-studies that he directed, Balassa (1978) regressed the growth rate of exports on the growth of output, both including and excluding exports from the measure of output. He found the strongest positive relationship when exports are included as part of output, but he also found a generally significant positive effect when exports are excluded from GNP. Krueger (1978, chp. 11) also finds that when the growth of exports was faster the growth of GNP was also faster. She did not find, however, that the extent of trade and exchange rate liberalization independently affects growth. Using data based on the indices of liberalization in the Papageorgiou-Michaely-Choksi study, Ioannis Kessides (1991) runs a number of regressions

Mexico, Malaysia, Pakistan, the Philippines, and for comparison, a developed country, Norway.

${ }^{6}$ This study resulted in published volumes that analyzed Chile, Colombia, Egypt, Ghana, India, Israel, Korea, the Philippines, and Turkey. 
relating liberalization and growth. Among his findings are that strong liberalization episodes are associated with higher increases in the rate of GDP growth than weaker episodes and that countries with sustained liberalization episodes experienced larger increases in the rates of GDP growth than countries with failed liberalization episodes.

As this brief survey of individual country studies and cross-country statistical analyses of inward-looking versus outward-looking policies indicates, the many differences among researchers in the issues focussed on and in the economic techniques employed make is difficult to draw many firm conclusions. One generalization that seem warranted is that the importsubstitution approach was not successful in promoting appreciably higher growth rates on a longrun, sustainable basis for developing countries that wanted to participate in the global economy. Most countries that used this approach were forced eventually to abandon it because of chronic balance-of-payments and budget-deficit problems. Those that have basically stuck with an inward-looking approach over the years, e.g., Pakistan, Burma, and Zimbabwe, have had relatively lower growth rates. In contrast, although many developing countries that switched to outward-looking policies were also often forced to abandon these policies temporarily because of unexpected external events or domestic political pressures related to the adjustment problems involved, those that were able to sustain these policies over long periods seem to have grown more rapidly. Another point that stands out in the various country studies is that outwardlooking and inward-looking policies involve much more than just trade and trade policies. For example, a willingness to welcome foreign direct investment, to maintain market-oriented exchange rates, to keep the money supply under fairly tight control, to constrain government budget deficits and corruption, and to control monopolistic behavior by firms and industries all

\footnotetext{
${ }^{7}$ The countries included in this effort were Argentina, Brazil, Chile, Columbia, Greece, Indonesia, Israel, Korea, New Zealand, Pakistan, Peru, the Philippines, Portugal, Singapore, Spain, Sri Lanka, Turkey, Uruguay, and
} 
seem to be important components of outward-looking development policies. Attempting to isolate the relative importance on growth of a particular component such as the volume of exports or liberal versus protectionist trade policies does not seem to make much sense, since there are complex interrelationship among these types of policies that make them highly intercorrelated. In his influential review of the various investigations of trade and growth through the early 1990s, Sebastian Edwards (1993) is especially critical of the early cross-country statistical studies, which he argues are based on overly simplistic theoretical models and also are flawed for various econometric reasons. More recently, T.N. Srinivasan and Jagdish Bhagwati (2001) have also sharply criticized cross-country regression analyses as the basis of determining the relationships between trade openness and growth. In their view, due to the weak theoretical foundations of most of these studies, the poor quality of the data bases they must use, and inappropriate econometric techniques utilized in many instances, nuanced, in-depth studies of country experiences are the best approach for understanding the linkage between trade and growth.

\section{Openness and the New Growth Theory}

Under the traditional comparative-statics framework, either in the absence or presence of economic distortions, changes in trade policy lead only to one-time changes in levels of production, although in the real world of economic frictions one might expect to observe the shift to new equilibria take place only over a number of years.. Similarly, trade-policy changes in the standard neo-classical model of exogenous growth brings about changes in the pattern of product specialization but not in the steady-state rate of growth. An important analytical development in the latter part of the 1980s and early 1990s, however, was the significant improvement in endogenous growth theory by such authors as Paul Romer (1986), Robert Lucas (1988) and 
Gene Grossman and Elhanan Helpman (1991). Part of this new growth theory focussed on the relationships between international trade and growth. One of the models of Grossman and Helpman (1991, Chp. 6) illustrates the types of relationships stressed in the new growth theory and, in particular, how trade policy can affect growth rates. To keep the model as simple as possible, they assume that each country is "small" in the sense of facing fixed world prices for the two final goods produced. There are two factors of production, human capital (skilled labor) and unskilled labor whose supplies are fixed. One of the final goods is produced with human capital and a fixed amount of differentiated, nontraded intermediate inputs, while the other is produced with unskilled labor and the same bundle of intermediate inputs. The nontraded intermediate inputs are produced under monopolistically competitive conditions with both factors of production. Constant returns to scale prevail for final and intermediate goods.

Human capital is also involved in the research and development activities that create new varieties of intermediate goods. These intermediate inputs are the key to increased productivity: each final good requires a given aggregate of intermediates but the more varieties there are in this aggregate, the higher output becomes. This captures the idea that dividing tasks into smaller and smaller parts through specialization leads to increasing returns. Another important aspect of the $R \& D$ process is that it not only produces new varieties of intermediates but also adds to the stock of knowledge, which is non-appropriable. The greater this stock of knowledge, the less the quantity of human capital needed to produce new varieties of intermediate inputs. Thus, the growth process is endogenous with $\mathrm{R} \& \mathrm{D}$ creating new intermediate inputs that increase the productivity of the needed aggregate of inputs and also add to the stock of general knowledge. In turn, the larger stock of knowledge reduces the amount of human capital needed for producing 
new varieties of intermediates. The equilibrium outcome is a constant rate of growth of factor productivity and a constant rate of output growth in the sectors producing the final goods.

Now consider the effects of a tariff on the imported good. If the country is importing the good that only uses human capital as a direct input and exporting the good intensively using unskilled labor, the import duty will raise the relative domestic price of the human capitalintensive good and via the Stolper-Samuelson theorem raise the relative wages of skilled labor. This increase in the price of human capital will lower the level of R\&D activity by raising its costs and thus lead to a lower equilibrium growth rate. In contrast, if the country imports the unskilled labor-intensive goods, import protection will lower the relative wages of skilled labor and accelerate the growth rate. Thus, in this model there no definite answer to whether protection increases or decreases the growth rate. It depends on the pattern of imports and exports. Besides using the concept of increasing returns as the driving force for endogenous growth, Grossman and Helpman (1991) and other growth theorists have introduced such concepts as knowledge spillovers resulting from trade in goods and foreign direct investment as well as the ability to imitate the products of foreign producers as engines of endogenous growth. Import protection generally reduces growth rates under these formulations.

\section{More Sophisticated Cross-Country Studies, Yet Continued Disagreement}

Motivated by the improvements in growth theory, the criticisms of earlier statistical analyses, the availability of more comprehensive data and new econometric techniques, economists devoted renewed attention in the 1990s to more sophisticated cross-country econometric analyses relating various measures of "outwardness" or "openness" to the growth rates of GDP or total factor productivity. Almost all of these studies find a strong positive relationship between outward-looking policies and growth. However, in an important detailed 
review of the most influential of these studies in which they focus on the effects of policyinduced trade barriers on growth rather than on the growth effects of more general measures of openness, Francisco Rodriguez and Dani Rodrik (2001) express skepticism "that there is a strong negative relationship in the data between trade barriers and economic growth, at least for levels of trade restrictions observed in practice." Moreover (p. 39), they "view the search for such a relationship as futile." A unique feature of the Rodriguez-Rodrik analysis is that they use the various authors' actual data sets in undertaking various tests of the robustness of their results. The rest of this section examines the main studies reviewed by Rodriguez and Rodrik (1999) and considers the criticisms they make of these studies.

As Rodriguez and Rodrik point out, one of the most widely cited statistical investigations of outward orientation and growth is by David Dollar (1992). (This paper was not covered in Edward's 1993 review.) Dollar bases his measure of outward orientation on estimates of the comparative price levels in 95 countries of an identical bundle of consumption goods calculated by Robert Summers and Alan Heston (1988). As a means for eliminating that part of the differences in prices among countries due to country differences in the prices of nontradeables, Dollar first regresses their price estimates on the level and square of GDP per capita as well as regional dummies and then compares the predicted price levels from this regression with the Summer-Heston prices. The argument is that if factor prices are not equalized, the relative prices of nontradables should vary systematically with differences in relative factor endowments. Since good data on relative factor endowments is not available for most less developed countries, he uses per capita income as a measure of per capita factor availability. Even with this procedure, he still finds significant anomalies for some countries with respect to the degree of trade distortion produced by his comparative price measure. However, when he combine this trade- 
distortion measure with a measure of the degree of volatility of exchange rates, he finds that the number of anomalies declines substantially.

Trade economists have often explored the possibility of measuring the degree of import protection or export subsidization by comparing domestic prices across countries for specific traded goods. However, this has generally been rejected as an adequate method of measuring trade barriers, since even for physically identical goods for which detailed direct information on levels of protection or subsidization exists, price differences are generally not good measures of differences in the degree of trade distortions. Given this result and the rather rough method used to purge the effects of the prices of nontradeable in the Summers-Heston price measures, it is not surprising that Dollar finds that his price indices do not yield reasonable results for a number of countries. Combining these indices with a measure of the volatility of exchange rates may give more reasonable results but, as Rodriguez and Rodrik argue, his variability index seems to be more a measure of economic instability at large rather than of trade orientation alone.

To test for the relationship between growth and his measures of outward orientation, Dollar regresses growth in per capita income in 95 countries averaged over the period 1976-85 on his trade distortion and exchange rate volatility measures as well as on the rate of investment in these countries over the same period. He finds that the higher the level of trade distortion and the greater the exchange rate variability for a country, the lower the rate of per capita GDP growth. Rodriguez and Rodrik not only have some theoretical criticisms of Dollar's trade distortion index as an appropriate measure of trade restrictions but find that the regression results for this index are not very robust to alternative specifications of the growth equation. For example, when dummy variables are added for Latin America, East Asia, and Sub-Saharan Africa, the trade distortion measure is not statistically significant. Adding initial per capita 
income and level of education reduce the explanatory power of this variable even more.

Furthermore, when Rodriguez and Rodrik use the latest revision of the Summers and Heston data base for the same countries and time period covered by Dollar, the trade distortion index is not significant and has the wrong sign even without the addition of regional dummies. However, the exchange rate variability index continues to be negative and statistically significant under all specifications both with the new and old database. Thus, while Dollar has shown that exchange rate variability is negatively associated with growth rates, I agree with Rodriguez and Rodrik that he has not demonstrated that outward orientation as one would expect this to be affected by trade policies is significantly related to economic growth in the developing countries he studied.

The next, equally influential study critiqued by Rodriguez and Rodrik is by Jeffrey Sachs and Andrew Warner (1995). These authors construct a zero-one dummy of openness for 79 countries that takes a zero if any one of the following five conditions holds over the period 197089: average tariff rate are over 40 percent on capital goods and intermediates, nontariff barriers cover 40 percent or more of imports of capital goods and intermediates, the country operates under a socialist economic system, there is a state monopoly of the country's major exports, and the black market premium on its official exchange rate exceeded 20 percent in the 1980s or 1990s. A value of zero is viewed as indicating a closed economy, while a value of 1 indicates an open economy. Controlling for such variables as the investment rate, government spending as a fraction of GDP, secondary and primary schooling, and number of revolutions and coups, Sachs and Warner find their openness index to be positively related to the growth rate of per capita GDP in a statistically significant sense.

In reanalyzing the Sachs-Warner data, Rodriguez and Rodrik find that two of the five indicators provide most of this statistical significance: the existence of a state monopoly of the 
country's major exports and a black market foreign exchange premium of more than 20 per cent. (Neither the measure of tariff levels or the coverage of nontariff trade barriers is statistically significant when the different indicators of openness are entered separately.) Moreover, they note that the state monopoly variable only covers 29 African countries undergoing structural adjustment programs in the late 1980s and early 1990s and, therefore, is virtually indistinguishable from the use of a Sub-Saharan Africa dummy. As for the statistical significance of the black-market premium, they argue that this indicator is likely to be a measure of policy failure due to many other reasons besides simply trade policy.

Another paper critiqued by Rodriguez and Rodrik is one by Sebatian Edwards (1998), the author of the review of the various studies on the trade and growth through the 1980s and early 1990s mentioned earlier, i.e., Edwards (1993). One of Edward's main criticisms in that paper of the cross-country statistical studies in that period is their failure to test in a systematic way for the robustness of the results obtained. In his 1998 paper, Edwards tries to remedy this shortcoming. He tests the robustness of the extent to which nine different measures of trade policy are related to total factor productivity growth. His nine measures of openness are: (i) the Warner-Sachs index just discussed; (ii) a subjective World Bank classification of trade strategies; (iii) Edward Leamer's (1988) index of openness based on the residuals from regressions explaining trade flows; (iv) the average black market premium on a country's official foreign exchange rate; (v) average levels of import tariffs calculated by UNCTAD and taken from Barro and Lee (1994); (vi) the average coverage of nontariff trade barriers taken from the same source; (vii) a subjective index of trade distortions formulated by the Heritage Foundation; (viii) the ratio of taxes on imports and exports to total trade; and (ix) a regression-based index of import distortions calculated by Holger Wolf (1993). He regresses these nine different measures of 
openness on estimates that he calculates of ten-year averages of total factor productivity from 1960-90 for 93 developed and developing countries. Controlling for initial per capita GDP in 1965 and the average number of years of education in 1965, he finds that six of the nine measures of openness are statistically significant in the expected direction.

Rather ironically, given Edward's emphasis on the need to test for robustness by using alternative specifications, Rodriguez and Rodrik find that his results are heavily dependent on the fact that he weighs his regressions by per capita GDP. If one weighs by the log of per capita GDP or uses White's (1980) method of dealing with the heteroskedasticity problem, the number of Edward's nine openness measures that are significant drops to five and four, respectively. The four significant openness measures that are significant when White's correction for heteroskedasticity is used are the World Bank's subjective classification of trade regimes, the black market exchange-rate premium, the subjective index of trade distortions calculated by the Heritage Foundation, and the ratio of trade taxes to total trade. With respect to the latter variable, Rodriguez and Rodrik find that recalculating this variable based on more recent data than was not available to Edwards fails to yield a significant sign when introduced into the regression on total factor productivity. They also note that the Heritage Foundation index was calculated for trade restrictions existing in 1996, whereas Edward's estimates cover the decade of the 1980s. When they calculate a similar index that is based on 1980s data, it is no long statistically significant in explaining the growth rate of total factor productivity. They also object to the use of this measure as well as the one from the World Bank as being subjective measures that they believe are "apparently highly contaminated by judgement biases or lack robustness to use of more credible information from alternative data sources". Finally, as 
mentioned earlier, they regard changes in the exchange rate premium as being influenced more by basic macroeconomic policies than trade policies.

Two additional recent papers on the subject are by Jeffrey Frankel and David Romer (1999) and by David Dollar and Aart Kraay (June 2001). Frankel and Romer directly address the question: Does trade cause growth? Like others, they point out that OLS regressions of per capita income on the ratio of export or imports and other variables, which generally find a positive relationship between trade shares and income per person, may not indicate the effect of trade on growth due to the endogeneity of the trade share. Countries whose incomes are high for reasons not related to trade may have high trade ratios. They, therefore, use geographic characteristics of countries that they believe are not influenced by incomes or government policies and other factors affecting income to obtain instrumental variables estimates of trade's effect on income. Specifically, they include in their trade equation the size of countries, their distance from each other, whether they share a border, and whether they are landlocked. Their main finding is that there is no evidence that ordinary least-squares estimates overstate the effects of trade. They are careful to point out, however, that this does not mean that changes in trade resulting from policy actions affect growth in the same manner as from their geographic variables, because there are many different mechanisms by which trade can affect income. But they argue (see Frankel and Romer, p. 395) that the effects of geography-based differences in trade are "at least suggestive about the effects of policy-induced differences."

Rodriguez and Rodrik also critique this paper and argue that the geographically constructed measure by Frankel and Romer may not be a valid instrumental variable. The reason is that geography is likely to be a determinant of income through many more channels than just trade. For example, distance from the equator affects public health and thus productivity through 
exposure to various diseases. When they include distance from the equator or percentage of land in the tropics, or a set of regional dummies in the Frankel-Romer instrumental-variable income regressions, their constructed trade-share variable is no longer statistically significant. However, Frankel and Romer report that when they also include distance from the equator as a control variable there is still no evidence that ordinary least-squares regressions overstate the influence of trade on income.

The final paper considered here is one by David Dollar and Aart Kraay (2001). The unique feature of their regression analysis is its focus on within-country (rather than crosscountry) decadal changes in growth rates and changes in the volume of trade, which the authors regard "as an imperfect proxy for changes in trade policy." Because of this approach, they argue, their results are not driven by geography or other unobserved country characteristics that influence growth but vary little over time, such as institutional conditions. They also introduce period dummies to control for shocks that are common to all countries, such as global demand shocks or reductions in transportation costs. Their data set consists of 187 observations on growth in the 1990 s and on growth in the 1980 s, covering roughly 100 countries.

Dollar and Kraay find a strong and significant positive relationship between the effect of changes in trade on changes in growth in their instrumental-variable regressions. Moreover, introducing a measure of the willing of individuals to hold liquid assets via financial intermediaries (interpreted as a measure of the quality of a country's institutions) as well as other omitted policies that affect growth and are correlated with increases in trade, such as changes in government expenditures as a share of gross national product, changes in the rate of inflation, and changes in the number of revolutions, does not change the high level of statistical significance of changes in the volume of trade. However, if these last three variables are 
regarded as endogenous to growth and the authors, therefore, simultaneously instrument for all of the right-hand variables, the result is a loss of statistical significance of the changes-in-tradevolume variable. They conclude, consequently, "that the available data on trade, growth and other policies may not be sufficiently informative to enable us to isolate the precise partial effect of trade on growth, since our instruments are not sufficiently informative."

\section{Conclusions}

What are we to conclude from this survey of empirical studies about the relationships between openness and growth, besides the fact that there is disagreement among economists on the matter? As noted in the introductory section, a key reason for the disagreement seems to relate to differences among authors in what they mean by the concept of openness. Rodriguez and Rodrik, for example, focus on the relationship between growth and trade openness, as reflected by "policy-induced barriers to international trade." In appraising the various studies they cover, they consider levels of import duties and measures of the restrictiveness of nontariff barriers to be the most appropriate indicators of trade openness. They are aware, however, of the limitations of the existing measures of these indicators of trade openness. Simple tariff averages weighted by imports tend to underweight the restrictiveness of high tariffs due to the low level of imports. (A tariff so high that there are no imports is a case in point.) Available comprehensive measures of nontariff barriers only measure the number of different type of nontariff trade barriers that a country has introduced and thus do not distinguish between the degree of restrictiveness of these measures.

In contrast to Rodriguez and Rodrik, most authors both of studies of development episodes in particular countries and of statistical analyses of such periods across a large number of countries study much more than just the effects of trade policies. The country studies led by 
Bhagwati-Krueger and Papageorgiou-Michaely-Choksi, for example, specifically focus on exchange rates as well as trade barriers and also examine the monetary, fiscal and regulatory policies that accompanied market-opening or market-closing episodes. This is why these writers as well as those undertaking cross-country statistical studies describe the effects of the policies they are studying on a country in terms of such broad phrases as its outward-orientation and openness in describing the policies they are studying. However, according to Rodriguez and Rodrik: "To the extent that the empirical literature demonstrates a positive causal link from openness to growth, the main operational implication is that governments should dismantle their barriers to trade."

Most of the authors of this literature would, I think, strongly object to this narrow interpretation of the policy implications of their work. While they generally favor the reduction of high tariff and non-tariff barriers in developing countries, these authors also call for other policy changes aimed at eliminating large government deficits, curtailing inflationary monetary policies, maintaining market-oriented exchange rates, increasing competition among domestic firms, reducing government corruption, improving the education system, strengthening the legal system and so forth. As the country studies have clearly demonstrated, not only are high tariff levels usually associated with highly restrictive nontariff measures, export subsidies to selected sectors, overvalued exchange rates, large government deficits, extensive rent-seeking and corruption, unstable governments, and so forth, but significant reductions in trade barriers are also accompanied by important liberalization efforts in these non-trade policy areas. The extensive multicolinearity among the policy variables affecting these conditions is the reason why both researchers who undertake both cross-country statistical analyses and individual country studies often try to combine various policies into a single index of economic openness or 
use a broad openness measure such as price differences that clearly are affected by much more than just trade policies affecting the individual commodities.

The general strategy followed by Rodriguez and Rodrik in critiquing the various studies involves examining the individual components of the general measures of openness used by the authors to find out if the tariff and nontariff trade components in these measures are by themselves related to economic growth in a statistically significant manner, determining if introducing plausible additional variables not directly related to trade policy change the significance levels of the trade variables, and exploring whether modifying the econometric techniques followed in a seemingly reasonable manner results in a loss of significance of the trade variables. As the summary of their findings presented in this paper show, they generally find that tariffs and nontariff coverage either are not statistically significant by themselves or lose their significance when other variables are added in the regression equations or different econometric techniques are utilized.

It is quite true that those recommending changes in economic policies in developing countries sometimes make statements implying that just lowering trade barriers will raise growth rates, and we should be grateful to Rodriguez and Rodrik for pointing out that the available empirical evidence does not support this claim. Of course, the quality of the existing data on the restrictiveness of tariffs and nontariff trade barriers is so poor that when better data become available we may find this relationship may indeed hold under certain circumstances. But, it is a caricature of the positions of most economists in academia or in governmental institutions to maintain that they fail to realize and recommend the necessity of policy changes beyond just those covering trade to stimulate sustained increases in growth rates. Especially since the Bhagwati-Krueger and Papageorgiou-Michaely-Choksi country studies, economists have 
emphasized the need, as a minimum, for a stable and non-discriminatory exchange-rate system and the need for prudent monetary and fiscal policies and corruption-free administration of economic policies for trade liberalization to be effective in the long-run.

The evidence that a general policy position of openness is preferable to long-run economic growth than an inward-looking policy stance should not be interpreted, however, as implying that no government interventions, such as selective production subsidies or controls on short-term capital movements, are appropriate at certain stages of development. We know from the individual country studies that policy-makers in some economies, such as South Korea, in shifting from policies favoring import-substitution policies to an outward-oriented policy approach actively intervened to promote exports. Some authors maintain that they succeeded in spite of these interventionist activities due to the predominance of liberalizing policies, but it may be that some of these government actions actually helped to raise growth rates. In my view, the individual country and cross-country studies support the conclusion that, on balance, general economic openness is much more favorable to growth than a general inward-looking economic approach but that some policies regarded as causing static economic distortions may be appropriate at certain times and under various circumstances. As Rodrik (2002) argues in an introductory essay to a series of country studies he has organized, we urgently need more studies that try give guidance on just what these times and circumstances are. One type of study that should be undertaken more extensively is the careful monitoring of the direct and indirect effects of liberalization measures from the outset of their introduction.

The statistical finding that increases in exports and increased growth are generally positively related in a significant statistical sense also involves the problem of causation. The export increase may be result of trade policy changes, other nontrade policy actions, or forces 
unrelated to a government's policy actions. As noted earlier, the export increase also may be the consequence of economic growth rather than the cause. Furthermore, the use of exports as an openness measure has the drawback of being a component of GDP, the usual measure of economic growth.

Consequently, as Rodriguez and Rodrik argue, not only does the search for the relationship between trade barriers and growth seem futile, but it does not even seem to make much sense to investigate what the empirical evidence is on this relationship in view of the complex interrelationships between trade policy and other government policies and various macroeconomic variables when one is talking about trade policy actions covering a wide group of goods, e.g., manufactures, rather than a particular industry. Actually most of the country studies, particularly the later ones, have been concerned with government policies that cover much more than narrowly-defined trade barriers to international trade.

It is true developing countries are often given the policy advice that decreasing trade barriers is a more effective way of achieving higher sustainable rates of growth than tightening trade restrictions. But, those giving such advice also emphasize the need, as a minimum, for a stable and non-discriminatory exchange-rate system and usually also the need for prudent monetary and fiscal policies and corruption-free administration of economic policies for trade liberalization to be effective in the long-run. It seems to me that the various country studies do support this type of policy advice and that the cross-country statistical studies do not overturn this conclusion. But the recent critiques of these latter studies demonstrate that we must be careful in attributing any single economic policy, such as the lowering of trade barriers, as being a sufficient government action for accelerating the rate of economic growth. 


\section{References}

Baldwin, Robert E. (1969), “The Case Against Infant-Industry Tariff Protection,” Journal of Political Economy, 77, 295-305.

Balassa, Bela and Associates (1971), The Structure of Protection in Developing Countries, Baltimore: The Johns Hopkins Press.

--------- (1978), “Exports and Economic Growth: Further Evidence,” Journal of Development Economics, 5, 181-189.

Barro, Robert J and Jong-Wha Lee (1994), “Data Set for a Panel of 138 Countries,” Harvard University, January.

Bhagwati, Jagdish (1978), Foreign Trade Regimes and Economic Development: Anatomy and Consequences of Exchange Control Regimes, New York: National Bureau of Economic Research.

Clemens, Michael A., and Jeffrey G. Williamson, “A Tariff-Growth Paradox? Protection’s Impact the World Around 1875-1997,’ NBER Working Paper No. 8459, September 2001. Dollar, David (1992), “Outward-oriented Developing Economies Really Do Grow More Rapidly: Evidence from 95 LDCs, 1976-1985," Economic Development and Cultural Change, $523-544$.

Edwards, Sebastian (1993), “Openness, Trade Liberalization, and Growth in Developing Countries," Journal of Economic Literature, XXXI, 1358-1393.

-------- (1998), “Openness, Productivity and Growth: What Do We Really Know?” Economic Journal, 108, 383-398.

Frank, Charles, Jr., Kwang Suk Kim and Larry E. Westphal (1975), Foreign Trade Regimes and Economic Development: South Korea, New York: National Bureau of Economic Research. 
Frankel, Jeffrey A. and David Romer (1999), “Does Trade Cause Growth?," American Economic Review, 89, 379-399.

Grossman, Gene M. and Elhanan Helpman (1991), Innovation and Growth in the Global Economy, Cambridge, MA:The MIT Press.

Hamilton, Alexander (1913), Report on Manufactures (1791), Reprinted in U.S. Senate

Documents, XXII, no. 172, Washington: US Congress.

Harrison, Ann (1996), “Openness and Growth: A Time-Series, Cross-Country Analysis for Developing Countries," Journal of Development Economics, 48, 419-447.

Hausmann, Ricardo and Dani Rodrik (2002), "Economic Development as Self Discovery," Centre for Economic Policy Research Discussion Paper No. 3356 (May).

Irwin, Douglas A. (2002), "Did Import Substitution Promote Growth in the Late Nineteenth Century," NBER Working Paper No. 8751 (February).

Kessides, Ioannis N. (1991), Appendix A2 in Michael Michaely, Demetris Papangeorgiou, and Armeane M. Choksi, Lessons of Experience in Developing World, Oxford: Basil Blackwell. Krueger, Anne O. (1997), “Trade Policy and Economic Development: How We Learn,” American Economic Review, 87,1,1-22.

Leamer, Edward (1988), "Measures of Openness," in R.E. Baldwin (ed.), Trade Policy and Empirical Analysis, Chicago: University of Chicago Press.

Little, Ian, Tibor Scitovsky and Maurice Scott (1970), Industry and Trade in Some Developing Countries: A Comparative Study, Cambridge: Oxford University Press.

List, Frederick (1856), National System of Political Economy, Translated by G. A. Matile, Philadelphia: Lippincott. 
Lucas, Robert E. (1988), “On the Mechanics of Economic Development,” Journal of Monetary Economics, 22, 3-42.

Meade, James E. (1955), Trade and Welfare, New York: Oxford University Press.

O'Rourke, Kevin (2000), “Tariffs and Growth in the Late $19^{\text {th }}$ Century," Economic Journal, $110 \mathrm{~m} 456-483$.

Prebisch, Raul (1950), The Economic Development of Latin America and its Principal Problems, Lake Success: United Nations, Department of Economic Affairs.

Rodriguez, Francisco and Dani Rodrik (2001), “Trade Policy and Economic Growth: A Skeptic's Guide to the Cross-National Evidence," in Ben Bernanke and Kenneth S. Rogoff, eds., NBER Macroeconomics Annual 2000, , Cambridge, MA: MIT Press for NBER.

Rodrik, Dani (October 2001), “The Global Governance of Trade As If Development Really Mattered," New York, N.Y.: United Nations Development Programme (UNDP).

Rodrik, Dani (February 2002), “Institutions, Integration, and Geography: In Searach of the Deep Determinants of Economic Growth,” see Rodrik’s home page, http://ksghome.harvard.edu/ .drodrik.academic.ksg/index.html

Romer, Paul M. (1986), “Increasing Returns and Long-run Growth,” Journal of Political Economy, 94, 1002-37.

Sachs, Jeffrey and Andrew Warner, "Economic Reform and the Process of Global Integration," Brookings Papers on Economic Activity, 1995:1, 1-118.

Srinivasan, T.N. and Jagdish Bhagwati, “Outward-Orientation and Development: Are Revisionists Right?” in Deepak Lal and Richard H. Snape (eds.) Trade, Development and Political Economy: Essays in Honour of Anne O. Krueger, New York: Palgrave. 
Summers, Robert and Alan Heston (1988), “A New Set of International Comparisons of Real

Product and Price Levels: Estimates for 130 Countries," Review of Income and Wealth, 34, 1-25.

White, Halbert L. (1980), “A Heteroskedasticity-Consistent Covariance Matrix Estimator and a

Direct Test for Heteroskedasticity," Econometrica, 48, 817-38.

Wolf, Holger (1993), “Trade Orientation: Measurement and Consequences,” Estudios de

Economia, 20, 52-72. 